\title{
Peningkatan Kadar Lipoprotein-Associated Phospholipase A2 Meningkatkan Kejadian Stroke Iskemik Akut
}

\author{
Syarif Indra ${ }^{1 *}$, Islahuddin Ibnu Amin ${ }^{1}$ \\ ${ }^{1}$ Bagian Neurologi Fakultas Kedokteran Universitas Andalas/ RSUP. Dr. M. Djamil, Padang, Indonesia \\ email : indrasyarifneuro@gmail.com \\ ${ }^{2}$ Bagian Neurologi Fakultas Kedokteran Universitas Andalas/ RSUP. Dr. M. Djamil, Padang, Indonesia
}

\begin{abstract}
Abstrak
Pendahuluan Stroke adalah penyebab kematian nomor dua di dunia setelah penyakit jantung dan penyebab disabilitas pada dewasa. Beberapa penelitian terbaru memperlihatkan bahwa kadar Lp-PLA2 serum yang tinggi ikut berkontribusi menyebabkan terjadinya stroke iskemik. Beberapa penelitian menunjukkan adanya hubungan antara serum Lp-PLA2 dengan kejadian stroke iskemik, sedangkan beberapa peneliti lain tidak mendapatkan adanya hubungan. Tujuan penelitian untuk mengetahui hubungan serum Lp-PLA2 dengan kejadian stroke iskemik. Metode Penelitian ini merupakan studi analitik komparatif dengan desain potong lintang dilakukan di bangsal Penyakit Saraf RS. DR. M. Djamil Padang antara bulan Oktober 2013 sampai bulan April 2014. Subjek terdiri dari 44 orang penderita stroke iskemik dan 44 orang kontrol sehat. Analisis statistik menggunakan uji parametrik dengan uji t tidak berpasangan, uji normalitas dengan Kolmogorov-Smirnov, dan analisis regresi logistik. Nilai $\mathrm{p}<0,05$ dianggap bermakna secara statistik. Hasil penelitian Umur rata-rata penderita stroke iskemik adalah $37.30 \pm 8.86$ tahun, jenis kelamin perempuan pada kelompok penderita stroke iskemik adalah 23 orang (52.3\%). Kadar rata-rata Lp-PLA2 serum pada kelampok penderita stroke iskemik adalah $103,49 \pm 48,00$ $\mathrm{ng} / \mathrm{mL}$. Kesimpulan Didapatkan hubungan yang bermakna antara kadar Lp-PLA2 serum dengan kejadian stroke iskemik dengan $\mathrm{p}<0,05$. Terdapat hubungan yang bermakna pada peningkatan kadar Lp-PLA2 serum dengan kejadian stroke iskemik
\end{abstract}

Katakunci - Lp-PLA2 serum, stroke iskemik

Abstract

Introduction: Stroke is a major health problem in the world, and associated with mortality, disability, and economic burden. Stroke is the second leading cause of death in the world after heart disease and cause of disability in adults. Several recent studies show that levels of Lp-PLA2 contribute to high serum lead to ischemic stroke, whereas some others do not get the association. Aims: studies an association between serum Lp-PLA2 with incident ischemic stroke. Method: This study is a descriptive analytic comparative with cross sectional design in the Neurology ward RS. DR. M. Djamil Padang between October 2013 to April 2014 with total of 88 subjects consisting of 44 subjects ischemic stroke patients and 44 healthy control group who participated in the study. Statistical analysis is used parametric test with unpaired t test, test for normality with the Kolmogorov-Smirnov test, and logistic regression analysis. Result: $P$ value 0.05 was considered statistically significant. The mean age of subjects in the group of ischemic stroke patients was $57.30 \pm 8.86$ years old. Female in patients with ischemic stroke group was 23 people (52,3\%). Mean levels of Lp-PLA2 serum in patiens with ischemic stroke group was $103.49 \pm 48.00 \mathrm{ng} / \mathrm{mL}$. A significan association between serum levels of Lp-PLA2 with incident ischemic stroke with $p<0.05$. Conclusion: There was a significant relation in elevation of serum Lp-PLA2 levels with incident of ischemic stroke.

Keywords - serum Lp-PLA2, ischemic stroke 


\section{Pendahuluan}

Stroke merupakan masalah kesehatan utama di dunia, terkait dengan tingkat kematian, kecacatan, dan beban ekonomi. ${ }^{1}$ Stroke adalah penyebab kematian nomor dua di dunia setelah penyakit jantung. Lebih dari 5,7 juta kernatian akibat stroke setiap tahunnya, dimana $87 \%$ terjadi di negaranegara miskin dan berkembang. ${ }^{1}$ Tendapat lebih kurang 16 juta kasus baru stroke setiap tahunnya, dan secara global terdapat lebih dari 50 juta penderita stroke dan Transient Ischemic Attack (TIA), dan $\geq 1$ dari 5 penderita akan mengalami serangan stroke lagi dalam 5 tahun. ${ }^{2}$ Selain itu terdapat 64,5 juta penderita stroke yang mengalami kecacatan dan membutuhkan bantuan dalam aktivitas sehari-hari, ${ }^{1,2}$

Di Indonesia, berdasarkan data Riset Kesehatan Dasar (Riskesdas) tahun 2007 stroke adalah penyebab kematian utama pada usia diatas 5 tahun baik didaerah perkotaan maupun di pedesaan (proporsi 19,4\% di perkotaan dan $16.1 \%$ di pedesaan). Prevensi stroke di Indonesia adalah delapan per seribu penduduk atau $0,8 \%$. $^{1,5}$

Peningkatan prevalensi stroke dapat dihambat dengan mengetahui dengan baik faktor risiko dan cara-cara pencegahannya. Penemuan faktor resiko stroke yang baru akan memberikan cara yang baru juga dalam pencegahan stroke. ${ }^{2}$ Lipoprotein-associated phospholipase A2 (Lp-PLA2) merupakan salah satu biomarker proinflamasi yang diyakini terlihat pada proses patologi stroke. ${ }^{3}$ Lp-PLA2 adalah enzim yang tidak terikat kalsium dan berhubungan dengan low density lipoprotein (LDL). ${ }^{3} \quad$ Lp-PLA2 merupakan enzim yang menghidrolisa fosfolipid oksidatif, menghasilkan lisofosfatidilkolin, yang merupakan marker proinflamasi yang langsung terlibat dalam pembentukan aterosklerosis dan plak yang ruptur. ${ }^{4}$ Sejak tahun 2005, the US Food anf Drug Administration (FDA) telah menyetujui pemeriksaan darah untuk Lp-
PLA2 untuk memeriksa pasien-pasien yang beresiko menderita stroke iskemik. ${ }^{3,4}$

Lipoprotein-associated phospholipase A2 (Lp-PLA2) yang dikenal juga dengan nama platelet-activating factor acetylhydrolase (PAF-AH) adalah suatu enzim $\mathrm{Ca}^{+2}$ independent phospholipase dengan berat molekul $50 \mathrm{kD}$. Enzim ini terutama dihasilkan oleh makrofag, limfosit dan sel mast dan serta merupakan subtipe dari superfamili fosfolipase A2 yaitu kelompok enzim yang menghidrolisis fosfolipid.

Plak aterosklerotik terutama inti lipid (lipid core) dan makrofag dalam kapsul fibrosa lesi yang akan ruptur (rupture prone lesion) mengékspresikan Lp-PLA2. Oleh karena itu Lp-PLA2 dapat dipakai sebagai penanda destabilisasi plak sebelum terjadi ruptur plak arteri. $^{5,6}$

Sekitar 80\% Lp-PLA2 berikatan dengan apo$\mathrm{B}$ dari LDL dan aktivitas enzim ini terutama terdapat pada small dense LDL (sd LDL). ${ }^{5}$ Sedangkan sisanya berikatan dengan high density lipoprotein (HDL) dan very low density lipoprotein (VLDL). Penelitian Gazi et al mendapatkan bahwa aktivitas Lp-PLA2 total dalam plasma lebih tinggi pada sdLDL dibanding $\mathrm{LDL}^{5,7}$

Lp-PLA2 akan berikatan dengan apo-B dari LDL dan sdLDL. Lp-PLA2 bersama dengan LDL dan sdLDL, masuk ke dalam tunika intima arteri yang mengalami disfungsi endotel. LDL akan mengalami oksidasi menjadi ox LDL. Reseptor Lp-PLA2 ditemukan dalam oxLDL dan Lp-PLA2 akan berikatan dengan reseptornya dan akan menghidrolisis gugusan asil pendek pada posisi sn-2 fosfolipid dari oxLDL membentuk dua mediator lipid yang bioaktif yaitu lysophosphatidylcholine (LysoPC) dan asam lemak teroksidasi (OxFA) yang berperan penting dalam proses aterosklerosis. Kedua produk tersebut memiliki efek proinflamasi yaitu berperan dalam inisiasi dan perkembangan ateroma. ${ }^{6,8}$ 
Lp-PLA ${ }_{2}$ merupakan marker yang spesifik untuk inflamasi vaskuler dan terlihat pada kejadian rupture-prone plaque. Peningkatan kadar Lp-PLA 2 serum mengindikasikan adanya rupture-prone plaque dan sebagai prediktor independent yang kuat terhadap risiko kardiovaskuler seperti CAD, MI. dan stroke Secara klinis, Lp-PLA 2 bertubungan dengan peningkatan risiko CHD dan terdapat banyak fakta dari studi epidemiologi yang antara Lp-PLA 2 dengan risiko penyakit kardiovaskuler ${ }^{8,9}$

Tujuan dari penelitian ini adalah untuk mengetahui hubungan peningkatan kadar Lp$\mathrm{PLA}_{2}$ serum dengan kejadian stroke iskemik.

\section{Metode Penelitian}

Penelitian ini merupakan studi deskriptif analitik komparatif dengan desain potong lintang (cross sectional). Penelitian ini dilaksanakan 6 bulan mulai dari bulan Oktober 2013 sampai bulan April 2014, di ruang rawat inap bagian Penyakit Saraf RS. DR. M. Djamil Padang, Jumlah sampel pada penelitian ini sebanyak 88 orang terdiri dari 44 orang subjek penderita stroke iskemik dan 44 orang subjek sehat sebagai kelompok kontrol. Pengambilan sampel dilakukan secara consecutive sampling. Kriteria inklusi penelitian ini adalah pasien dengan diagnosis stroke iskemik akut berdasarkan anamnesis, pemeriksaan fisik, dan Brain CT scan, serta bersedia ikut penelitian dengan menandatangani informed consent. Data yang diambil mencakup karakteristik dari (umur, jenis kelamin), riwayat hipertensi dan diabetes mellitus, kadar Lp.PLA2 serum. Analisi statistik yang digunakan adalah uji parametik dengan uji t tidak berpasangan, uji normalitas dengan Kölmogorov-Smirnov, dan analisis regresi logistik. Kemaknaan statistik ditentukan jika $\mathrm{p}<0,05$.

\section{HASIL}

Penelitian dilakukan terhadap 44 orang pasien stroke iskemik akut yang memenuhi kriteria inklusi dan 44 orang subjek kontrol sehat dan dilakukan pemeriksaan kadar lipoprotein-associated phospholipase A2 serum pada kedua kelompok tersebut, Sebagian besar subjek penelitian adalah perempuan. Median umur penderita stroke adalah 56 tahun (42-79 tahun) dan 52.5 tahun (41-66 tahun) pada kontrol sehat.

Sebaran data untuk subjek pada penelitian ini terdistribusi secara normal, dan setelah dilakukan uji $t$ tidak berpasangan untuk melihat perbedaan rerata umur antara kelompok penderita stroke iskemik akut dengan kelompok kontrol didapatkan perbedaan yang bermakna pada rerata umur kelompok pasien stroke iskemik akut dengan kelompok kontol $(\mathrm{p}=0,001)$

Sementara sebaran data jenis kelamin pada penelitian ini tidak terdistribusi secara normal dan setelah dilakukan uji Mann Whitney tidak didapatkan perbedaan yang bermakna antara jenis kelamin kelompok penderita stroke iskemik akut dengan jenis kelamin kelompok control dengan $\mathrm{p}=0,832$

Distribusi karakteristik dasar subjek penelitian dapat dilihat pada Tabel 1 .

Tabel 1. Distribusi Karakteristik Dasar SUbJeK PENELITIAN

\begin{tabular}{|c|c|c|c|}
\hline Variabel & $\begin{array}{l}\text { Stroke } \\
\text { Iskemik } \\
(\mathrm{n}=44)\end{array}$ & $\begin{array}{l}\text { Kontrol } \\
(n=44)\end{array}$ & $\mathbf{P}$ \\
\hline \multicolumn{4}{|l|}{ Umur } \\
\hline Mean \pm SD & $57.30 \pm 8.86$ & $51.30 \pm 7.32$ & 0.001 \\
\hline $\begin{array}{c}\text { Median } \\
\text { (min-maks) }\end{array}$ & $56.60(42-79)$ & $52.50(41-66)$ & \\
\hline \multirow{2}{*}{\multicolumn{4}{|c|}{$\begin{array}{l}\text { Jenis } \\
\text { Kelamin }\end{array}$}} \\
\hline & & & \\
\hline Laki-laki & $21(47.7)$ & $20(45.5)$ & 0.832 \\
\hline Perempuan & $23(52.3)$ & $24(54.5)$ & \\
\hline
\end{tabular}


Dilakukan analisis bivariat untuk mencari hubungan kadar Lp-PLA2 dengan kejadian stroke iskemik akut. Hasil uji statistik didapatkan hubungan yang bermakna antara peningkatan kadar Lp-PLA2 dengan stroke iskemik akut $(\mathrm{p}=0,013)$, dan OR $5.73(95 \%$ CI 1.50-21.87), dimana peningkatan kadar Lp-PLA2 beresiko mengalami stroke iskemik 5.73 kali dibanding pasien dengan kadar Lp-PLA2 normal.

Hubungan Kadar Lp-PLA2 dengan stroke iskemik akut ditampilkan pada tabel 2 .

TABel 2. HUbungan KadAR LP-PLA2 DENGAN KEJADIAN STROKE ISKEMIK AKUT

\begin{tabular}{|c|c|c|c|c|c|c|c|}
\hline \multirow{3}{*}{ Lp-PLA2 } & \multicolumn{4}{|c|}{ Stroke Iskemik } & & \multirow{3}{*}{ OR } & \multirow{3}{*}{$\begin{array}{c}\mathbf{9 5 \%} \\
\mathrm{Cl}\end{array}$} \\
\hline & \multicolumn{2}{|c|}{ Ya } & \multicolumn{2}{|c|}{ Tidak } & & & \\
\hline & $\mathbf{n}$ & $\%$ & $\mathbf{n}$ & $\%$ & & & \\
\hline & 13 & 29.5 & 3 & 8.0 & 0.013 & 5.73 & $\begin{array}{l}1.50- \\
21.87\end{array}$ \\
\hline & 31 & 70.5 & 41 & 93.2 & & & \\
\hline Jumlah & 44 & 100.0 & 44 & 100.0 & & & \\
\hline
\end{tabular}

\section{Pembahasan}

Kerusakan endotel yang diikuti proses aterosklerosis pada pembuluh darah otak akibat hipertensi, diabetes mellitus dislipidemia akan memicu terjadinya proses aterosklerosis dan selanjutnya akan menyebabkan iskemik otak. ${ }^{11,12}$ Pada tahap awal stroke iskemik terjadi hipoperfusi serebral fokal yang menyebabkan gangguan pada suplai glukosa dan O2 di neuron. ${ }^{6,11}$

Keadaan ini menyebabkan terjadinya kegagalan energi dan metabolisme anaerobik dineuron yang menyebabkan penumpukan asam laktat intrasel yang bersifat toksik sehingga otak akan mengalami asidosis. ${ }^{12}$ Lp-PLA2 merupakan marker proinflamasi yang berperan dalam proses aterosklerosis dalam pembuluh darah, kadar Lp-PLA2 akan meningkat bila terdapat kondisi ruptur prone plaque yang akan berperan juga dalam terbentuknya thrombosis dan selanjutnya akan memperberat iskemia serebral. ${ }^{13,14}$
Proses sekunder yang terjadi pada stroke berupa rangkaian kematian neuron tertunda (delayed neuronal death) yang dimulai dari proses influks kalsium. Akumulasi kalsium intrasel menyebabkan aktivasi reseptor NMDA, AMPA dan Kainate yang semakin meningkatkan jumlah kalsium dalam sel neuron. ${ }^{12,15}$ Meningkatnya konsentrasi kalsium merangsang aktivasi enzim yang terkait calcium, salah satunya phospholipase A2 yang secara aktif menyebabkan disfungsi mitokondria dengan pelepasan mediator inflamasi, yang selanjutnya mengakibatkan kematian sel. ${ }^{15}$ Selain itu Phospholipase A2 juga mengaktifkan asam arakidonat yang selanjutnya mengaktivasi siklooksigenase dan lipooksigenase, yang selanjutnya mengaktifkan kaskade delayed neuronal death. Semua kondisi ini akan bermanifestasi sebagai gangguan fungsional (tingkat keparahan stroke) ${ }^{16,17}$

Pada penelitian ini terdapat peningkatan kadar Lp-PLA2 pada 13 subjek (29.5\%) dari penderita stroke iskemik. sedangkan pada kelompok kontrol kadar Lp-PLA2 meningkat pada 3 subjek (8\%). Secara statistik terdapat hubungan yang bermakna antara peningkatan kadar Lp PLA2 dengan kejadian stroke iskemik dengan nilai $\mathrm{p}=0,013,<0.05$ dan OR 5.73 (95\% Cl 1.50-21.87), dimana pasien dengan peningkatan kadar Lp-PLA2 beresiko mengalami stroke iskemik 5.73 kali dibanding pasien dengan Lp-PLA2 normal.

Sesuai dengan peneliti sebelumnya, Ballantyne et al 2005, melakukan sebuah penelitian prospektif berskala besar yang melibatkan sekitar 12.762 subjek sehat berusia pertengahan selama lebih kurang 6 tahun menunjukkan bahwa kadar Lp-PLA2 lebih tinggi pada subjek yang menderita stroke iskemik dibandingkan dengan kelompok subjek yang tidak menderita stroke iskemik. ${ }^{18}$

Sebuah studi kecil yang dilakukan oleh Satoh K, et al. tahun 1992 yang mengidentifikasi 33 subjek dalam 2 bulan 
setelah serangan stroke iskemik mendapatkan nilai mean \pm SD aktivitas LpPLA2 secara bermakna lebih tinggi pada kelompok control $(41 \pm 18 \quad \mathrm{nmol} / \mathrm{ml} /$ menit). ${ }^{19,20}$

\section{Kesimpulan Dan Saran}

Terdapat hubungan yang bermakna pada peningkatan kadar Lipoprotein- Associated Phospolipase A2 Serum dengan kejadian stroke iskemik akut. Disarankan untuk melakukan penelitian lebih lanjut dengan skala yang lebih besar dengan variabel variabel terkait lainnya.

\section{Daftar Pustaka}

[1] Zhou F, Liu Y, Shi H, Huang Q, Zhou J. Relation between lipoprotein-associated phospholipase A2 mass and incident ischemic stroke severity.Springer Neurological Science. 2018

[2] Huang Fubao, Wang K, Shen J. 2019.Lipoprotein-associated phospholipase A2:The story continues. Wiley Online Library

[3] Li D, Wei W, et al. 2017.Lipoprotein-associated phospholipase A2 and risks of coronary heart disease and ischemic stroke in the general population: A systematic review and metaanalysis. Elsevier

[4] Monbailliu T, Gossens J,Hachimi-Idrissi S. 2017.Blood protein biomarkers as diagnostic tool for ischemic stroke: a systematic review.Biomarkers in Medicine.

[5] Bejot Y, Bailly H, Durier J,Giroud M. 2016.Epidemiology of stroke in Europe and trends for the 21st century. Presse Med

[6] Garg P K, Norby F L, et al. 2018. Lipoproteinassociated phospholipase A2 and risk of incident peripheral arterial disease: Findings from The Atherosclerosis Risk in Communities study (ARIC).Elsevier

[7] Hu G, Liu D, Tong H, Huang W, Hu Y, Huang Y. 2019.Lipoprotein-Associated Phospholipase A2 Activity and Mass as Independent Risk Factor of Stroke: A Meta-Analysis. BioMed Research International

[8] Tian Y, Jia H, Li S, Wu Y, Guo L,Tan G, Li B..The associations of stroke, transient ischemic attack, and/or stroke-related recurrent vascular events with Lipoprotein-associated phospholipase A2 : A systematic review and meta-analysis.Medicine. 2017

[9] Dhamoon M S, Cheung Y K, Moon Y P, Wright Y B, Sacco R L, Elkind M S V. 2019. Interleukin-6 and lipoprotein-associated phospholipase A2 are associated with functional trajectories.PLOSONE

[10] Khoshnam S E,Winlow W, Farzaneh M.2017.The Interplay of MicroRNAs in the Inflammatory Mechanisms Following Ischemic Stroke. American Association of Neurophatologist.

[11] Rasyid A, Harris S, Kurniawan M, Mesiano T. Buku Ajar Neurologi: Stroke Iskemik. Fakultas Kedokteran Universitan Indonesia; 2017

[12] Caplan,L.R Caplan Stroke :A Clinical Approach. $4^{\text {th }}$ ed. United State of Amerika : Saunder Elsevier. 2009

[13] Katan M, Moon Y P, Paik M C, Wolfert R L, Sacco R L, Elkind M S V. 2014. LipoproteinAssociated Phospholipase A2 Is Associated with Atherosclerotic Stroke Risk: The Northern Manhattan Study

[14] Wang Y, Hu S, Ren L, Lei Z., Lan T, Cai J, Li C. 2018. Lp-PLA2 as a risk factor of early neurological deterioration in acute ischemic stroke with TOAST type of large arterial atherosclerosis

[15] Lin J, Zheng H, Cucchiara BL, et al. Association of Lp-PLA2-A and early recurrence of vascular events after TIA and minor stroke. Neurology. 2015

[16] Benjamin EJ, Virani SS, Callaway CW, et al. Heart Disease and Stroke Statistics-2018 update: a report from the American Heart Association. Circulation. 2018

[17] Benderly M, Sapir B, Kalter-Leibovici O, et al. Lipoprotein-associated phospholipase A2, and subsequent cardiovascular events and mortality among patients with coronary heart disease. Biomarkers. 2017

[18] Wei L, Ke Z, Zhao Y, et al. The elevated lipoproteinassociated phospholipase A2 activity is associated with the occurrence and recurrence of acute cerebral infarction. Neuroreport. 2017

[19] Ueshima H, Kadowaki T, Hisamatsu T, et al. Lipoprotein-associated phospholipase A2 is related to risk of subclinical atherosclerosis but is not supported by Mendelian randomization analysis in a general Japanese population. Atherosclerosis. 2016

[20] Gregson JM, Freitag DF, Surendran P, et al. Genetic invalidation of Lp-PLA2 as a therapeutic target: large-scale study of five functional Lp-PLA2-lowering alleles. Eur J Preventive Cardiol. 2017 